Note

\title{
Pharmacokinetics and Metabolic Effects of High-Dose Growth Hormone Administration in Healthy Adult Men
}

\author{
Toshiaki TANAKA, Yoshiki SEINO*, Kenji FUJIEDA**, Yutaka Igarashi***, Susumu YOKOYA\#, \\ KATSUHIKo TACHIBANA\#\# AND YUNOSUKe OGAWA \#\#\#
}

Department of Endocrinology \& Metabolism, National Children's Medical Center, Tokyo 154-8509

* Department of Pediatrics, Okayama University, Okayama 700-0914

** Department of Pediatrics, Hokkaido University, Sapporo 060-0814

*** Igarashi Pediatric Clinic, Sendai 981-3203

\# Department of Pediatrics, Toranomon Hospital, Tokyo 105-0001

\#\# Division of Endocrinology \& Metabolism Kanagawa Children's Medical Center, Yokohama 232-0066

\#\# Department of Pediatrics, Saitama Medical Center, Kawagoe 350-0844

\begin{abstract}
To evaluate pharmacokinetics of growth hormone (GH) and its effects on IGF-I, glucose, insulin, nonesterified fatty acid (NEFA) and triglyceride (TG), fifteen Japanese healthy adult male volunteers (20-27 years old) were studied. The subjects were divided into three groups, and received with a single s.c. injection of $0.075,0.15$ and $0.30 \mathrm{IU} / \mathrm{kg}$ of $\mathrm{GH}$, respectively. The subjects assigned to receive $0.30 \mathrm{IU} / \mathrm{kg}$ were administered for additional 6 days. After a single administration of $\mathrm{GH}, \mathrm{Cmax}$ and $\mathrm{AUC}$ of $\mathrm{GH}$ were increased in a dose-dependent manner. There was a significant positive correlation between the AUC and the $\mathrm{T} 1 / 2(\mathrm{r}=0.516, \mathrm{P}<0.05)$. Total body clearance was significantly greater in $0.075 \mathrm{IU} / \mathrm{kg}$ group than the other groups and showed a significant negative correlation with $\mathrm{Cmax}(\mathrm{r}=-0.694, \mathrm{P}<0.005)$ and AUC $(\mathrm{r}=-0.723, \mathrm{P}<0.005)$. After a single administration of each dose, serum IGF-I concentrations were increased gradually. In the repeated administered group $(0.30 \mathrm{IU} / \mathrm{kg})$, IGF-I concentrations almost reached a plateau at a significantly high level four days after the start of administration and remained at a high level (786-405.4 $\mathrm{ng} / \mathrm{ml})$ until day 8. There was no significant difference in diurnal change of blood glucose and serum insulin after a single administration of $\mathrm{GH}$ among three groups. In the $0.3 \mathrm{U} / \mathrm{kg}$ group, there was no significant difference in diurnal change of blood glucose between day 1 and day 7, but serum insulin level was significantly higher in day 7 than in day $1(P<0.01)$. Serum concentrations of NEFA were increased over time after administration in all subjects administered once or repeatedly. TG concentrations showed no changes after single administration of each dose level, but were significantly increased on day 7 in the subjects repeatedly treated with 0.30 $\mathrm{IU} / \mathrm{kg} /$ day. This effect is speculated to be caused by high dose $\mathrm{GH}$ treatment. The above findings demonstrated that higher GH dose significantly influences on carbohydrate and lipid metablism. It remains necessary to elucidate what kinds of effects of the long-lasting increased levels of insulin and triglyceride, even if reversible, would have on glucose and lipid metabolism.
\end{abstract}

Key words: High-dose GH, Insulin, Triglyceride, Healthy adult

(Endocrine Journal 46: 605-612, 1999)

SINCE human growth hormone (GH) has been produced by genetic recombinant technology in place

Received: November 19, 1998

Accepted: April 20, 1999

Correspondence to: Toshiaki TANAKA, M.D., Department of Endocrinology \& Metabolism, National Children's Medical Research Center, 3-35-31 Taishidoh, Setagaya-ku, Tokyo 154-8509 of extraction from the pituitary gland, there is no limitation of supply for $\mathrm{GH}$ treatment. It is now a consensus that $\mathrm{GH}$ treatment with replacement dose $(0.5 \mathrm{IU} / \mathrm{kg} /$ week used in Japan) is not enough to treat growth hormone deficiency (GHD) [1] as well as non-GHD short children [2]. Satisfactory therapeutic results have been reported with a high dose of $0.30 \mathrm{IU} / \mathrm{kg} /$ day in children with non-GHD short stature and with intrauterine growth retardation 
(IUGR) without serious adverse events [3-5].

In vivo and in vitro studies have shown that growth hormone (GH) has the effect on carbohydrate metabolism and lipid metabolism. Since clinical trials with high dose GH on non-GHD children have been conducted, it is necessary to investigate the effect of high dose GH on carbohydrate and lipid metabolism.

In the present study, the pharmacokinetics and metabolic effects of high dose GH was studied in healthy adult volunteers.

\section{Subjects and Methods}

\section{Subjects}

The subjects consisted of healthy volunteers with respect to previous history, weight (within $\pm 20 \%$ of standard weight), medical interview, blood pressure and pulse rate, body temperature, electrocardiography and laboratory tests (hematology, serum chemistry and routine urinalysis). Fifteen Japanese adult males aged from 20 to 27 years were recruited as the study subjects with an informed consent. They were divided into three groups and administered by a single subcutaneous injection of $0.075,0.15$ and $0.30 \mathrm{IU} / \mathrm{kg}(\mathrm{n}=5$ at each dose level) of recombinant GH (Norditropin; Novo Nordisk Pharma, Tokyo, Japan). The subjects assigned to receive $0.30 \mathrm{IU} / \mathrm{kg}$ were administered for additional 6 days.

\section{Study design}

The GH was administered at 9:00 a.m. after overnight fasting. A lunch, evening meal and snack were served at $13: 00,18: 00$ and $21: 00$, respectively. In the $0.3 \mathrm{IU} / \mathrm{kg}$ group, a breakfast was served at $9: 00$ before blood sampling on the day 2-6.

The subjects of the $0.3 \mathrm{IU} / \mathrm{kg}$ group took approximately $2500 \mathrm{cal} /$ day of meals containing $80 \mathrm{~g}$ protein and $80 \mathrm{~g}$ fat on average from day 2 to day 6 .

Blood samples were collected at $0,1,2,3,4,5,6$, 9,12 and 24 hours after single injection. In the 0.30 $\mathrm{IU} / \mathrm{kg}$ group, blood sampling was also performed at 24 hours after administration on days 2-6, and 0,1 , $2,3,4,5,6,9,12$ and 24 hours after administration on day 7. Blood glucose, serum GH, serum IGF-I and serum insulin were measured in these samples and triglyceride (TG) and non-esterified fatty acid (NEFA) were measured in the samples before and till 4 hours after GH administration on day 1 and day 7 . GH was measured by IRMA (GH kit [Daiichi], Daiichi Radioisotope), IGF-I (Somatomedin C [Chiba Corning], Chiron) and insulin by RIA (Insulin[Eiken], Eiken), and glucose by glucosedehydrogenase method. In the $0.30 \mathrm{IU} / \mathrm{kg}$ group, anti-GH antibody titer was determined by charcoal method before the initial administration and 14 days after the study period.

This clinical trial was approved by the Instirutional Review Board at Waseda Clinic.

\section{Statistical analysis}

Results are expressed as mean and standard deviation (SD) in the figures. The time interval from GH injection to maximum GH level was recorded as Tmax. To determine the elimination half-time $\left(T_{1 / 2}\right)$, a linear regression analysis was performed on the $\mathrm{GH}$ levels starting from $1 \mathrm{~h}$ after Tmax. The total body clearance of $\mathrm{GH}$ was calculated from the injected dose divided by the area under the curve (AUC) of GH.

The data obtained were statistically analyzed by the following methods: (i) homogeneity of background factors: Kruskal-Wallis test, (ii) comparison of laboratory data between the pretreatment and post treatment levels: Wilcoxon's signed rank sum test, (iii) comparison of changes in blood concentrations of each parameter between the dose groups: two-way analysis of variance and Tukey multiple comparison, and (iv) Pearson's correlation coefficient.

\section{Results}

The demographic data of the subjects are shown in Table 1. There was no significant difference among three groups in each parameter.

Serum GH concentrations after single administration and some of the calculated variables of the GH profiles are shown in Fig. 1 and Table 2. There was a significant, dose-dependent increase of the Cmax and the AUC. However, there was no significant difference in Tmax and $T_{1 / 2}$ among the three groups. Total body clearance was significantly 
Table 1. Demographic data of subjects

\begin{tabular}{lcccc}
\hline \multicolumn{1}{c}{ Group } & $\begin{array}{c}0.075 \mathrm{IU} / \mathrm{kg} \\
(\mathrm{n}=5)\end{array}$ & $\begin{array}{c}0.15 \mathrm{IU} / \mathrm{kg} \\
(\mathrm{n}=5)\end{array}$ & $\begin{array}{c}0.30 \mathrm{IU} / \mathrm{kg} \\
(\mathrm{n}=5)\end{array}$ & Significance* \\
\hline Age (year) & $22.4 \pm 1.3$ & $22.4 \pm 1.5$ & $24.4 \pm 2.6$ & NS \\
Height $(\mathrm{cm})$ & $171.5 \pm 7.5$ & $170.2 \pm 5.8$ & $170.2 \pm 2.3$ & NS \\
Weight $(\mathrm{kg})$ & $62.8 \pm 6.5$ & $65.1 \pm 7.5$ & $61.7 \pm 7.3$ & NS \\
\% overweight & $-2.2 \pm 6.6$ & $3.0 \pm 8.1$ & $-2.3 \pm 11.7$ & NS \\
\hline
\end{tabular}

*Kruskal-Wallis test NS: not significance

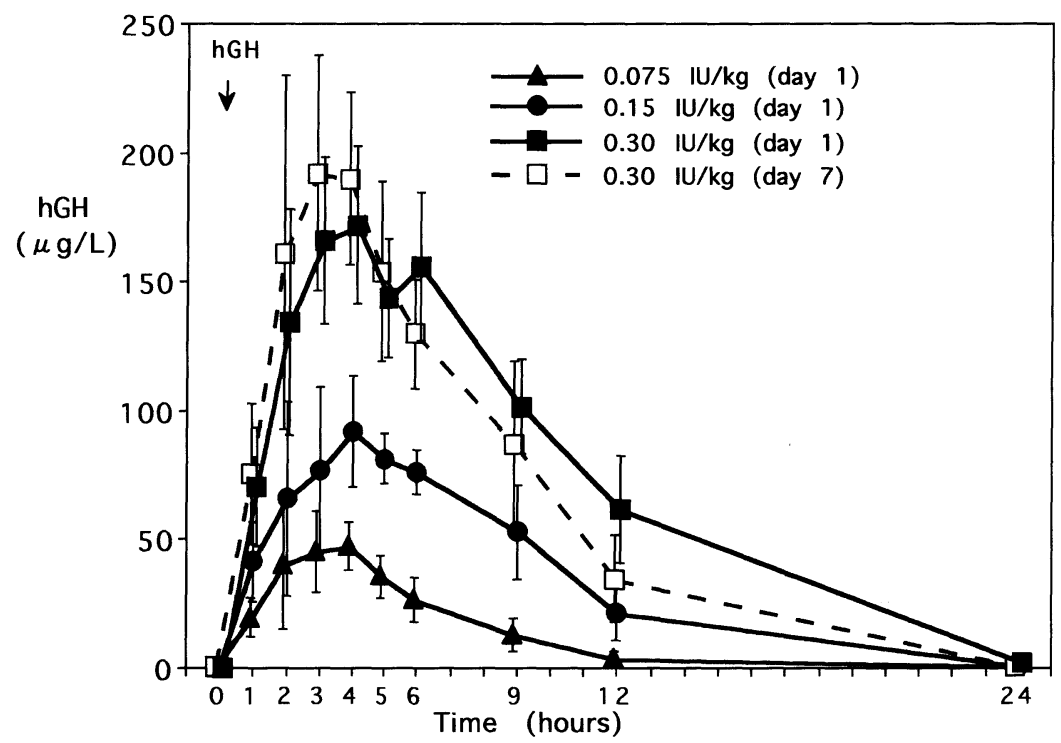

Fig. 1. Change in serum $\mathrm{GH}$ concentration after $\mathrm{GH}$ injection.

Table 2. Pharmacokinetics of GH administration

\begin{tabular}{|c|c|c|c|c|}
\hline Group & $0.075 \mathrm{IU} / \mathrm{kg}$ & $0.15 \mathrm{IU} / \mathrm{kg}$ & & $0.30 \mathrm{IU} / \mathrm{kg}$ \\
\hline $\mathrm{Cmax}(\mu \mathrm{g} / \mathrm{L})$ & $55.4 \quad(38 \sim 82)$ & $93.8 \quad(80 \sim 130)^{\mathrm{a}}$ & 180.0 & $(160 \sim 210)^{\mathrm{ab}}$ \\
\hline $\operatorname{AUC}(\mu \mathrm{g} / \mathrm{Lx} 24 \mathrm{~h})$ & $311.5 \quad(251.8 \sim 344.1)$ & $836.9 \quad(681.5 \sim 909.5)^{\mathrm{a}}$ & 1778.5 & $(1619.1 \sim 1958.1)^{\mathrm{ab}}$ \\
\hline Tmax (hr) & $3.6 \quad(2 \sim 5)$ & $4.4 \quad(3 \sim 6)$ & 4.1 & $(3 \sim 5)$ \\
\hline $\mathrm{T} 1 / 2(\mathrm{hr})$ & $2.28(1.47 \sim 3.00)$ & $3.08(1.99 \sim 3.87)$ & 3.57 & $(2.59 \sim 5.38)$ \\
\hline Clearance $(\mathrm{mL} / \mathrm{min})$ & $327.2 \quad(274.8 \sim 412.8)$ & $249.1 \quad(231.6 \sim 262.2)^{\mathrm{a}}$ & 228.1 & $(196.2 \sim 258.0)^{\mathrm{a}}$ \\
\hline
\end{tabular}

a Significant vs $0.075 \mathrm{IU} / \mathrm{kg}$ at $\mathrm{P}<0.05$ b Significant vs $0.15 \mathrm{IU} / \mathrm{kg}$ at $\mathrm{P}<0.05$

greater in $0.075 \mathrm{IU} / \mathrm{kg}$ group than the other groups. In the $0.30 \mathrm{IU} / \mathrm{kg}$ group, no significant difference was observed in diurnal change of serum GH concentrations between days 1 and 7 (Fig. 1). During the treatment period of 7 days, serum GH concentrations returned to the baseline 24 hours after each administration.

After single sc injection, IGF-I concentrations did not significantly change until 5-6 hours after the administration and increased gradually toward 24 hours
(Fig. 2), when the levels were significantly greater than those before injection. There was a significant difference in serum IGF-I level between the 0.075 and $0.30 \mathrm{IU} / \mathrm{kg}$ groups $(\mathrm{P}<0.005) 24$ hours after injection. There was a positive correlation between the AUC and IGF-I value 24 hours after a single injection, but it does not reach a significance $(r=$ $0.474, \mathrm{P}=0.074)$. In the $0.3 \mathrm{IU} / \mathrm{kg}$ group, serum IGF-I concentrations increased and reached nearly a plateau on day 4 , after which they remained 


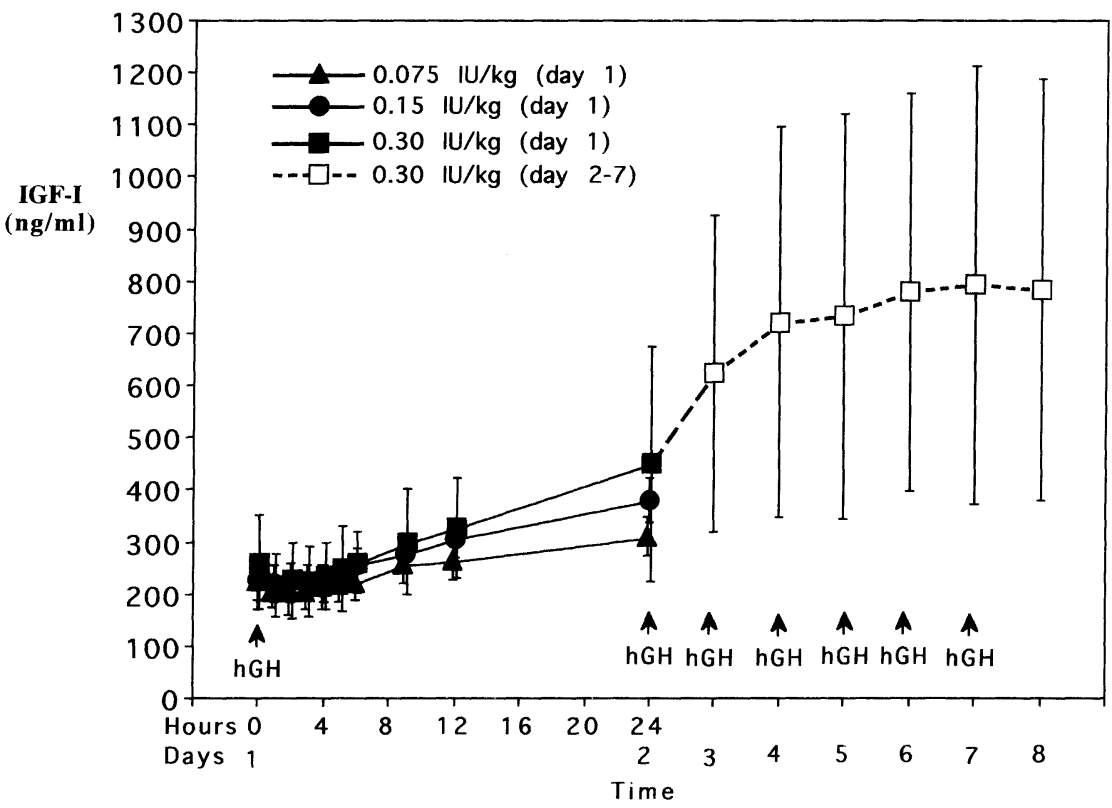

Fig. 2. Change in serum IGF-I after GH injection.

high until day 8 (Fig. 2). On day 8, IGF-I attained a significantly higher serum concentration of 405$786 \mathrm{ng} / \mathrm{ml}$ than on day 1 , which was comparable to the concentration of IGF-I normally seen during puberty.

There was no significant difference in diurnal change of blood glucose and serum insulin after a single administration of $\mathrm{GH}$ among three groups as shown in Fig. 3(a) (b). In the $0.3 \mathrm{U} / \mathrm{kg}$ group, there was no significant difference in diurnal change of blood glucose between day 1 and day 7, either (Fig. 3(a) (b)). However, blood insulin level was significantly higher in day 7 than in day $1(\mathrm{P}<0.01)$.

Serum concentrations of NEFA were increased over time after administration in all subjects administered once or repeatedly (Fig. 4). The timerelated changes were not significantly different among the three dose groups $(\mathrm{P}=0.33)$. Intragroup com-

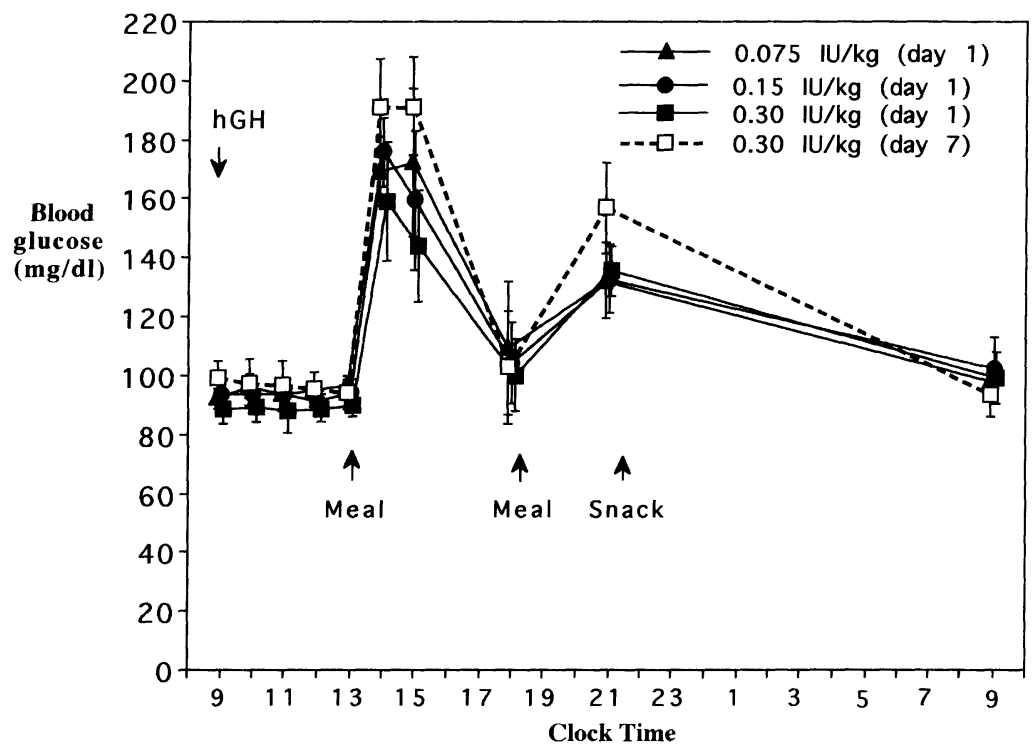

Fig. 3(a). Diurnal change of blood glucose. 


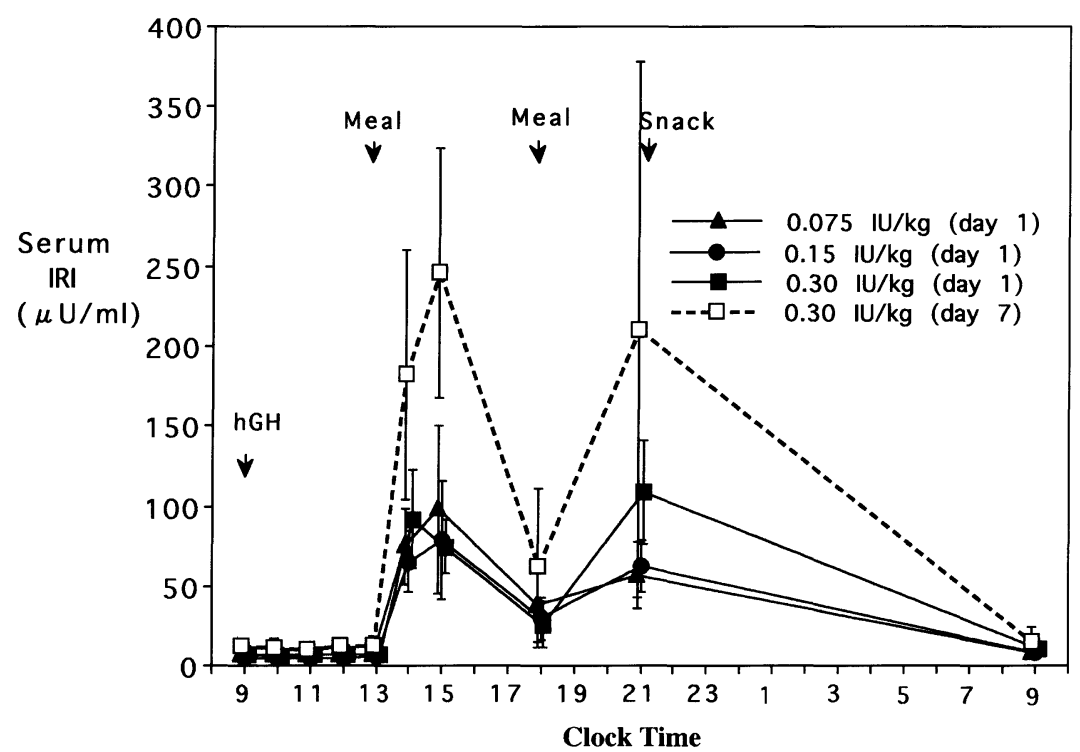

Fig. 3(b). Diurnal change of serum IRI.

parison in the repeatedly treated subjects also showed no significant difference in changes in NEFA concentrations between days 1 and 7 .

There was no significant difference in TG concentration among three groups after a single injection of GH (Fig. 5). In the $0.3 \mathrm{U} / \mathrm{kg}$ group, serum TG concentrations gradually increased during 7-day administration (Fig. 6) and serum TG level before GH injection on day 7 was significantly higher than the corresponding value on day 1 . But the TG level gradually declined in four hours after administration on day 7 (Fig. 6).
In the repeated administered group, anti-GH antibodies were not detected in any of the subjects 14 days after the treatment period.

No adverse events were found after single administration of 0.075 and $0.15 \mathrm{IU} / \mathrm{kg}$. In the 0.3 IU $/ \mathrm{kg}$ group, one subject complained of mild pain in the both knees on day 1, which disappeared without any treatment on day 2 . The same subject exhibited papules all over the both legs. This subject showed a negative response to DLST (drug-induced lymphocyte blastogenesis test) in all the tests using solvent, lyophilized powder and drug solution. At the fol-

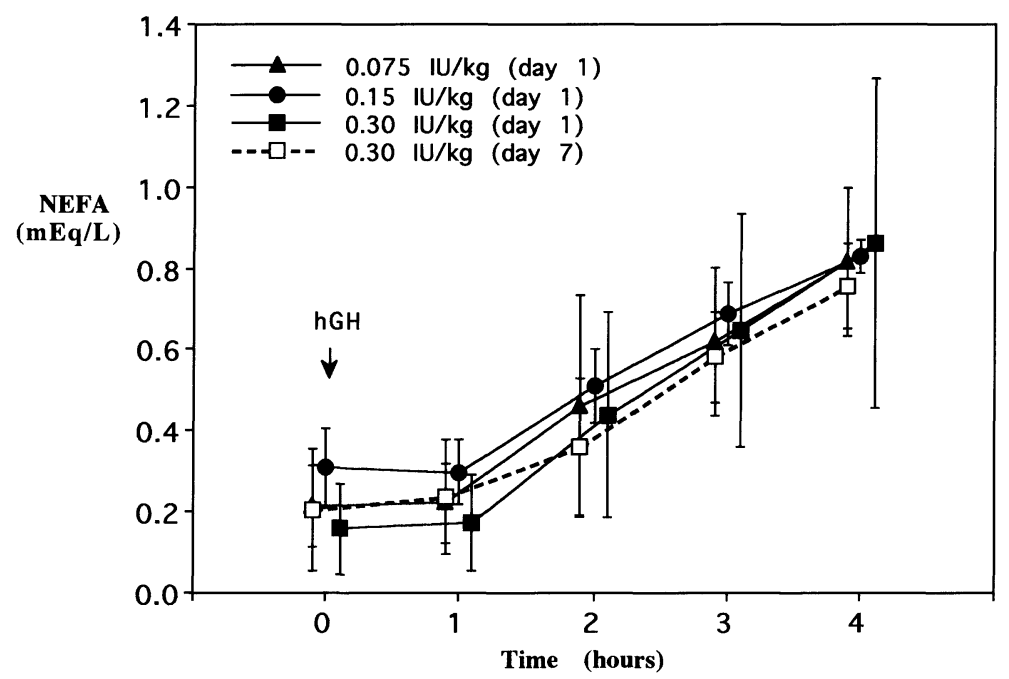

Fig. 4. Change in NEFA after GH injection. 


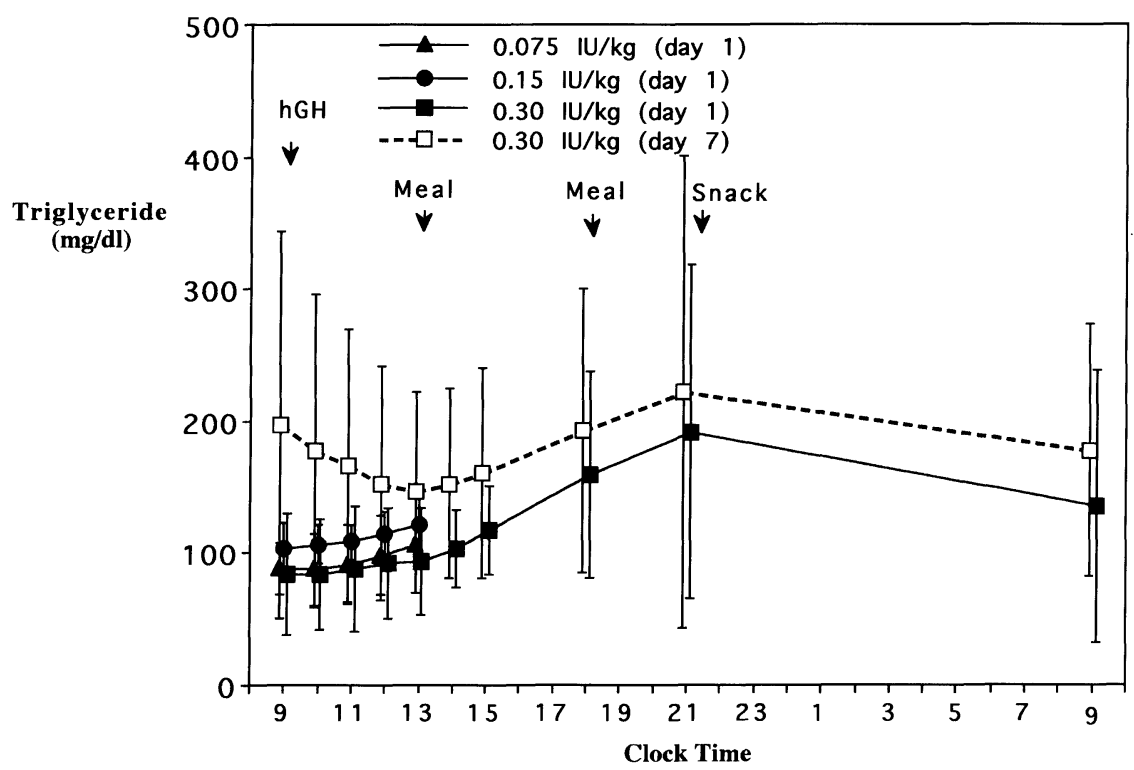

Fig. 5(a). Change in serum triglyceride after $\mathrm{GH}$ injection.

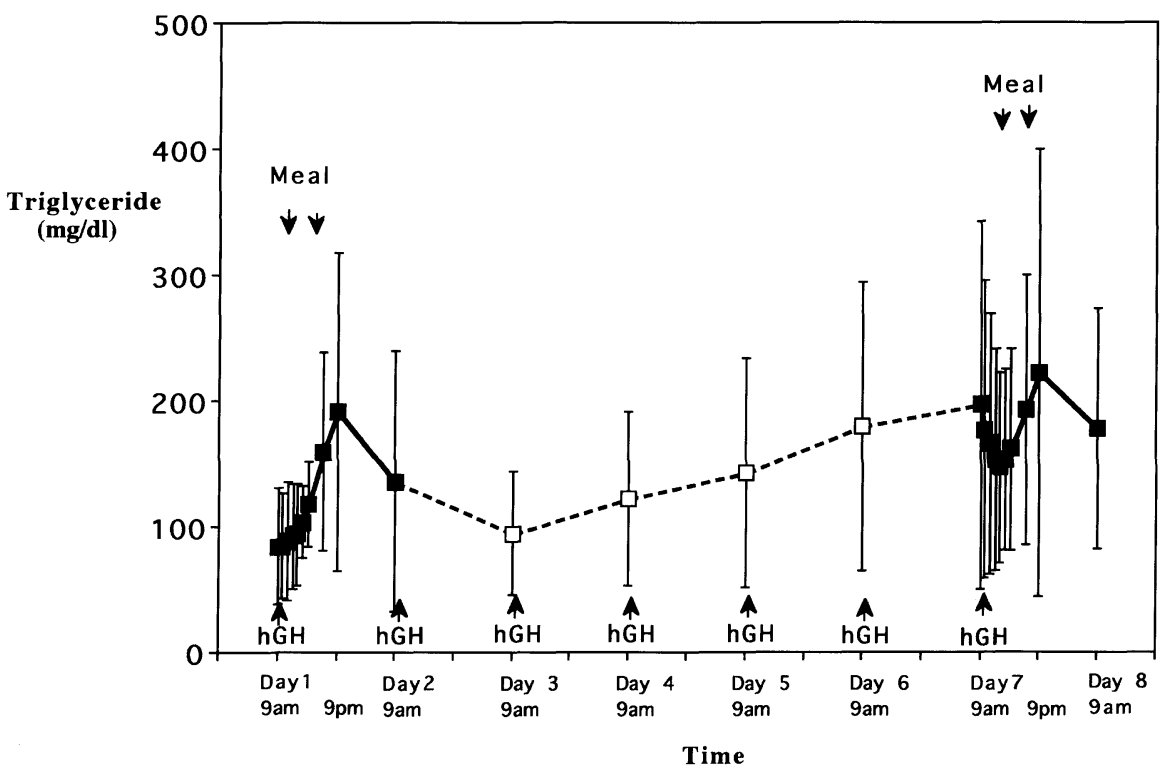

Fig. 5(b). Change in serum triglyceride in $0.3 \mathrm{IU} / \mathrm{kg}$ group.

low-up tests, the fraction of eosinophils in the blood was also within the reference range. Therefore, the causal relation to the drug was not definite. There were no abnormal laboratory findings after a single administration. In the $0.3 \mathrm{IU} / \mathrm{kg}$ group, changes in serum ALT, changes in serum TSH and urinary occult blood were recorded in 2, 1 and 1 subjects, respectively. However, these changes were not clinically significant.

\section{Discussion}

We have shown a significant dose-dependent increase of the Cmax and the AUC. This relation, to some extent, reflected in the serum IGF-I levels 24 hours after an injection. But the effect of the dose on IGF-I should be followed after several days, since serum IGF-I concentrations did not 
reach a plateau until on day 4 in $0.30 \mathrm{IU} / \mathrm{kg}$ group. The plateau level was compatible to the pubertal level and to the level of patients with intrauterine growth retardation (IUGR) treated with $0.3 \mathrm{IU} / \mathrm{kg} /$ day (5). In the IURG study (5), the high dose $\mathrm{GH}$ treatment significantly increased growth velocity and increased height SD score more than $2 \mathrm{SD}$ in two years. These findings suggest that high IGF-I level by high dose GH closely relates to increased height velocity. Since high dose trial has been conducted in children, it is reasonable to conduct this study in children. However, because of the ethical problem and the amount of blood drawn, high dose trial was conducted in adults.

A dose-dependent increase of the Cmax and the AUC is in agreement with the reports in GH deficient children [6] and in Turner syndrome [7]. However, maximum concentration of GH is higher in our study than in the others, though accurate dose comparison is difficult; they used $2 \sim 6 \mathrm{IU} /$ day or $4 \sim 8 \mathrm{IU} / \mathrm{m}^{2}$ /day. This difference may be caused by the difference in underlying diseases and/or in age, or even it may be explained by the different assays for $\mathrm{GH}$ measurement. Although there was no significant difference in Tmax and $T_{1 / 2}$ among three groups, there was a tendency that $T_{1 / 2}$ became longer in higher dose group and clearance was significantly smaller in higher dose groups than $0.075 \mathrm{IU} / \mathrm{kg}$ group. Even this smaller clearance at high dose, GH accumulation was not observed in $0.30 \mathrm{IU} / \mathrm{kg}$ group and the later plateauing of IGF-I was observed. This may indicate some saturation of the clearance mechanisms and some saturation of biological activities.

For glucose and insulin, only physiological changes in glucose concentrations due to food intake were observed with no significant difference being noted between days 1 and 7 in the $0.30 \mathrm{IU} / \mathrm{kg}$ group, but significant increased insulin level was observed on day 7 in the $0.30 \mathrm{IU} / \mathrm{kg}$ group. There are many reports that $\mathrm{GH}$ treatment increases plasma insulin in $\mathrm{GH}$ deficient children [6], GH deficient adults [8,9], non-GH deficient short children [4] and Turner syndrome [10], but glucose tolerance is not impaired. Our study is compatible with these reports. Prevalence of clinical diabetes is reported not to be increased in GH-treated children [11]. It is reasonable that replace dose of $\mathrm{GH}$ in
GH deficiency does not impair glucose tolerance. However, high dose GH treatment in Turner syndrome produced a significant increase in fasting and insulin levels [12]. It is possible that long term treatment with high dose of GH in non-GH deficient short children impair glucose tolerance, since acromegaly is associated with an increased prevalence of diabetes [13-15].

It is known that NEFA is increased in response to GH $[16,17]$. Also in this study, NEFA concentrations were increased over time, but not significantly different among the three dose groups. Comparison of this parameter in the repeated dose group also showed no significant difference between days 1 and 7. These results show that lipolytic effect of GH is not dose dependent in the dose range studied and NEFA accumulation is not observed in repeated injection of high dose GH.

TG concentrations showed no changes after single administration of each dose level, but were significantly increased on day 7 in the subjects repeatedly treated with $0.30 \mathrm{IU} / \mathrm{kg} / \mathrm{day}$. It has been reported that $\mathrm{GH}$ replacement therapy did not show any significant changes in TG concentration in adult GHD [8, 9]. In acromegalic patients, however, a mild or moderate hypertriglyceridemia and decreased lipoprotein lipase activity have been observed [18]. GH is known to stimulate the release of free fatty acid from fat cells resulting in an increased flux of free fatty acids to the liver. GH stimulates the esterification of oleic acid into triglyceride in hepatocytes from hypox rats [19] and decreases lipoprotein lipase release from rat epididymal fat in vitro [20]. Therefore, it is speculated that increased TG level observed in repeated administered group is caused by high dose $\mathrm{GH}$ treatment, since replacement $\mathrm{GH}$ treatment dose not influence on lipid metabolism in adult GHD $[8,9]$ and in GHD children [6]. Since hypertriglyceridemia is clinically important as a risk factor for atherosclerosis, further evaluation of the effects on TG is required in the long-term use of high-dose GH.

The above findings demonstrated that higher $\mathrm{GH}$ dose significantly influences on carbohydrate and lipid metabolism. It remains necessary to elucidate what kinds of effects of the long-lasting increased levels of insulin and triglyceride, even if reversible, would have on glucose and lipid metabolism. 


\section{Acknowledgement}

The authors thank Novo Nordisk for providing recombinant $\mathrm{GH}$.

\section{References}

1. Takano K, Tanaka T, Saito T (1994) Psychosocial adjustment in a large cohort of adults with growth hormone deficiency treated with growth hormone in childhood: summary of a questionnaire survey. Acta Paediatr Scand (supple) 399: 16-19.

2. Tanaka T, Hibi I, Takano K, Suwa S, Shizume K (1996) Four-year experience of growth hormone treatment in children with non-endocrine short stature. Clin Pediatr Endocrinol 5 (Suppl 7): 1-9.

3. Lesage C, Walker $\mathbf{J}$, Landier $\mathbf{F}$, Chatelain $\mathbf{P}$, Chaussain JL, Bougneres PF (1991) Near normalization of adolescent heiGHt with growth hormone therapy in very short children without growth hormone deficiency. J Pediatr 119: 29-34.

4. Walker J, Chaussain JL, Bourgneres PF (1989) Growth hormone treatment of children with short stature increases insulin secretion but does not impair glucose disposal. J Clin Endocrinol Metab 69: 253258.

5. de ZeGHer F, Maes M, Gargosky SE, Heinrichs C, Du Caju MVL, Thiry G, De Schepper J, Craen M, Breysem L, Lofstrom A, Jonsson P, Bouguignon J-P, Malvaux P, Rosenfeld RG (1996) high-dose growth hormone treatment of short children born small for gestational age. J Clin Endocrinol Metab 81: 18871892.

6. Jorgensen JOL, Flyvbjerg A, Lauritzen T, Alberti KGMM, Orskov H, Christiansen JS (1988) Doseresponse studies with biosynthetic human growth hormone $(\mathrm{GH})$ in $\mathrm{GH}$-deficient patients. $J$ Clin Endocrinol Metab 67: 36-40.

7. Teunenbroek AV, Keizer-Schrama SMPFM, Stijnen T, Jansen M, Otten BJ, Delemarre-Van de Waal HA, Vulsma T, Wit JM, Rongen-Westerlaken C, Drop SLS (1996) Yearly stepwise increments of the growth hormone dose results in a better growth response after four years in girls with Turner syndrome. J Clin Endocrinol Metab 81: 4013-4021.

8. Russell-Jones DL, Watts GF, Weissberger A, Naoumova R, Myers J, Thompson GR, Sönksen PH (1994) The effect of growth hormone replacement on serum lipids, lipoproteins, apolipoproteins and cholesterol precursors in adult growth hormone deficient patients. Clin Endocrinol 41: 345-350.

9. Beshyah SA, Henderson A, Niththyananthan R, Skinner E, Anyaoku V, Richmond W, Sharp RP,
Johnston DG (1995) The effects of short and long term growth hormone replacement therapy in hypopituitary adults on lipid metabolism and carbohydrate tolerance. J Clin Endocrinol Metab 80: 356363.

10. Wilson DM, France JW, Sherman B, Johanson AJ, Hints RL, Rosenfeld RG (1988) Carbohydrate and lipid metabolism in Turner syndrome: Effect of therapy with growth hormone, oxandrolone, and a combination of both. J Pediatr 122: 210-217.

11. Lippe BM, Kaplan SA, Golden MP, Hendricks A, Scott ML (1981) Carbohydrate tolerance and insulin receptor binding in children with hypopituitarism: responses after acute and chronic growth hormone administration. J Clin Endocrinol Metab 53: 507-513.

12. Weise M, James D, Leitner $\mathrm{CH}$, Hartmann $\mathrm{KK}$, Bohles HJ, Attanasio A (1993) Glucose metabolism in Ullrich-Turner syndrome: long-term effects of therapy with human growth hormone. Horm Res 39: 36-41.

13. Wass JAH, Cudworth AG, Bottazzo GF, Woodrow JC, Besser GM (1980) An assessment of glucose intolerance in acromegaly, and its response to medical treatment. Clin Endocrinol (Oxf) 12: 53-59.

14. Jadresic A, Banks LM, Child DF, Diamant L, Doyle FH, Fraser TR, Joplin GF (1982) The acromegaly syndrome. Relation between clinical features, growth hormone values and radiological characteristics of the pituitary tumours. $Q J$ Med 202: 189-204.

15. Nabarro JDN (1987) Acromegaly. Clin Endocrinol (Oxf) 26: 481-512.

16. Davidson MB (1987) Effect of growth hormone on carbohydrate and lipid metabolism. Endocr Rev 8: 115-131.

17. Press M (1988) Growth hormone and metabolism. Diabetes Metab Rev 4: 391-414.

18. Murase T, Yamada N, Ohsawa N, Kosaka K, Morita S, Yoshida S (1980) Decline of post heparin plasma lipoprotein lipase in acromegalic patients. Metabolism 29: 666-672.

19. Elam MB, Simkevich CP, Solomon SS, Wilcox HG, Heimberg M (1988) Stimulation of in vitro triglyceride synthesis in the rat hepatocyte by growth hormone treatment in vivo. Endocrinology 122: 1397-1402.

20. Murase T, Yamada N, Matsuzaki F (1981) The in vitro effect of growth hormone on adipose tissue lipoprotein lipase in rats. Life Sci 28: 199-201. 